DOI 10.4467/2543733XSSB.19.009.11408

AGATA KRZYWDZIŃSKA

Instytut Rosji i Europy Wschodniej UJ

Uniwersytet Jagielloński

\title{
WIZERUNEK POLSKI W ROSYJSKIEJ PRASIE W PRZEDEDNIU ODZYSKANIA NIEPODLEGLOŚCI (SZKIC PROBLEMATYKI NA BAZIE ,IZWIESTII” I „PRAWDY”)
}

\author{
The Image of Poland in the Russian Press \\ on the Eve of Regaining Independence \\ (Draft of the Problem Based on „Izviestia” and „Pravda”)
}

Summary

The present article attempts to present the synthetic picture of Poland in "Izvestia" and "Pravda" in 1917.

Key-words: Russian press, regaining independence, image of Poland

Słowa kluczowe: prasa rosyjska, odzyskanie niepodległości, wizerunek Polski

\section{Przedmiot analizy prasowej}

Analizie poddane zostały wybrane artykuły prasowe publikowane w dwóch tytułach prasy codziennej w Rosji w 1917 roku, w czasie niezwykle skomplikowanym politycznie i społecznie dla Rosji i podległego mu Królestwa Polskiego. Dotarcie do wszystkich materiałów źródłowych z 1917 roku jest wysoce utrudnione dla badacza w Polsce, natomiast w Rosji pozostały już nieliczne oryginalne egzemplarze wybranych gazet, co powoduje, że jest to zaledwie szkic problematyki, a zaprezentowana analiza ma charakter cząstkowy i nie może stanowić w pełni całościowego obrazu Polski i Polaków z tamtego okresu. 


\section{Krótka charakterystyka sytuacji polityczno-spolecznej}

Warto przypomnieć podstawowe fakty z roku 1917, by skonfrontować je z informacjami prasowymi rosyjskich dzienników, poświęconymi polskiej tematyce. Królestwo Polskie istniało wówczas jako państwo w pełni zależne od Rosji, którą w ciąu roku wstrząsnęły aż dwa przewroty rewolucyjne. Rewolucja lutowa doprowadziła do obalenia monarchii i przejęcia władzy przez Rząd Tymczasowy ${ }^{1}$. Powołano do życia rady delegatów żołnierskich i robotniczych, a największe znaczenie uzyskała wówczas Piotrogrodzka Rada Delegatów Robotniczych i Żołnierskich².

Skutkiem rewolucji tysiące Polaków zostało uwolnionych z więzień albo powróciło z zesłania, co przełożyło się na znaczny wzrost ich aktywności politycznej oraz dążeń niepodległościowych ${ }^{3}$.

W listopadzie 1917 roku (tj. w październiku według kalendarza juliańskiego) w Rosji doszło do kolejnej rewolucji, obalenia Rządu Tymczasowego, przejęcia władzy przez bolszewików i proklamacji republiki radzieckiej ${ }^{4}$. Dnia 10 listopada nowa Rada Komisarzy Ludowych wydała jako jedno z pierwszych postanowień „Dekret o prasie”, przywracający cenzurę zniesioną przez rewolucję lutową, a zabraniający jednocześnie wydań o charakterze kontrrewolucyjnym ${ }^{5}$. Należy nadmienić, że w rewolucji brało udział tysiące polskich rewolucjonistów, wierzących w odbudowę niepodległego państwa polskiego. Okazało się jednak, że musiało upłynąć jeszcze dziesięć miesięcy, do sierpnia 1918 roku, by Rosja anulowała traktaty rozbiorowe; niemniej relacje sąsiedzkie i tak nie uległy poprawie ${ }^{6}$.

\section{Charakterystyka analizowanych gazet i artykułów}

\section{Ad. 1 ,Izwiestija”}

Dla nowo powstałej po rewolucji lutowej Rady Piotrogrodzkiej stworzono specjalnie organ prasowy, zatytułowany „Извъстія Петроградскаго совъта рабочихъ депутатовъ (w tłumaczeniu dosłownym „Wiadomości Piotrogrodzkiej Rady roboczych i żołnierskich deputatów") $)^{7}$. Jego pierwszy numer ukazał się 28 lutego (13 marca) 1917 roku.

Interesujące jest, że redakcję gazety umieszczono w budynku, w którym wcześniej mieściła się redakcja gazety „Kopiejka”. Warto odnotować, że wraz z przeniesieniem rządu z Piotrogrodu do Moskwy w 1918 roku również redakcja gazety „Извьстія...” zmieniła adres na moskiewski.

\footnotetext{
${ }^{1}$ J. Smaga, Rosja w 20 stuleciu, Kraków 2001, s. 19.

${ }^{2}$ Ibidem, s. 25.

${ }^{3}$ Prof. Andrzej Andrusiewicz, historyk dziejów Europy Wschodniej, wskazał w jednym z wywiadów, że
} liczba Polaków mieszkających w Rosji w tamtym czasie wynosiła $4 \mathrm{mln}$. Źródło: Nie tylko Dzierżyński, ,,Tygodnik Przegląd", 11 grudnia 2017 r. https://www.tygodnikprzeglad.pl/nie-tylko-dzierzynski/ Data dostępu: 2018.12.29.

${ }^{4}$ J. Smaga, op. cit., s. 27, 28.

${ }^{5}$ J. Adamowski, Rosyjskie media i dziennikarstwo czasów przełomu (1985-1997), Warszawa 1998, s. 53.

${ }^{6}$ A. Andruszewicz, Nie tylko Dzierżyński [w:] ,Tygodnik Przegląd” 11 grudnia 2017 r., rozmowę przeprowadził P. Dybicz, https://www.tygodnikprzeglad.pl/nie-tylko-dzierzynski/ Data dostępu: 2018.12.29.

7 „Izwiestija”, nr 209, 28 X 1917 r. 
Gazeta stała się oficjalnym organem prasowym, w którym drukowano najważniejsze dokumenty prawne, analizy i komentarze. To „Izwiestija” opublikowały najistotniejsze dokumenty rewolucji październikowej, między innymi „Dekret o ziemi”, ogłoszony 8 listopada 1917 przez Ogólnorosyjski Zjazd Rad, który znosił prywatną własność ziemi, czy specyficznie rozumiany przez bolszewików „Dekret o pokoju”, który wzywał narody walczące do wyrzeczenia się aneksji i zaborów ${ }^{8}$.

„Izwiestija” szybko nazwano gazetą rosyjskiej inteligencji, ponieważ stała się forum wypowiedzi znanych pisarzy i poetów (m.in. Włodzimierza Majakowskiego, Maksima Gorkiego). Niewątpliwie wpływ na zawartość tematyczną i ogólny wydźwięk polityczny „Izwiestii” miał ich pierwszy redaktor naczelny, Jurij Michajłowicz Stiekłow, członek partii komunistycznej od 1893 roku i aktywny uczestnik rewolucji 1905-1907 w Rosji. Publikował w gazetach bolszewickich „Звезда” і „Правда”. W 1910 roku Stiekłow został postawiony przez Piotra Stołypina, premiera i ministra spraw wewnętrznych Rosji, przed alternatywa - albo uda się na Syberię, albo za granicę. Zdecydowawszy się na wyjazd zagraniczny, wszedł w skład paryskiej sekcji bolszewików ${ }^{10}$. W czasie rewolucji lutowej 1917 roku został wybrany na członka komitetu wykonawczego Rady Piotrogrodzkiej ${ }^{11}$.

„Izwiestija” od początku publikowały - oprócz dekretów i odezw, artykuły naświetlające bieżącą sytuację polityczno-społeczną w Rosji i w znacznie mniejszym stopniu za granica.

Wydarzenia wewnętrzne 1917 roku całkowicie pochłonęły uwagę redaktorów „Izwiestii”, którzy w swych tekstach skupiali się na nacjonalizacji fabryk, banków czy cerkwi. Warto nadmienić, że wówczas bolszewicy rozpoczęli prześladowanie partii niebolszewickich (w tym socjalistycznych - eserowców i mienszewików), dochodziło do aresztowań, zabójstw i zmuszania ich członków do emigracji.

„Izwiestija” pisały o krajach sojuszniczych, poruszając sprawy proleteriackie, propagując bolszewizm, rozpowszechniając idee socjalistyczne. Pytanie zatem kluczowe, czy Polska była wówczas przedmiotem zainteresowania „Izwiesti” i w jakim stopniu? Pobieżna analiza wybranych artykułów prasowych pokazuje, że Polska i Polacy nie stanowili ważnego punktu odniesienia dla redaktorów w roku 1917. Polska wspominana była tylko w kontekście wewnętrznych wydarzeń politycznych, zdecydowanie ważniejsze miejsce w rubrykach zagranicznych zajmowały takie kraje jak Francja i stosunki rosyjsko-francuskie. Brakowało przychylnych artykułów i pogłębionych analiz dotyczących sytuacji w Polsce. Gdy temat rewolucji obejmował inne narody, pojawiały się polskie nazwiska działaczy rewolucyjnych i apele o integrację środowisk bolszewickich. O Polsce wspomniano w kontekście obalonej władzy carskiej. Odezwy rewolucyjne, drukowane na pierwszych stronach gazety, miały na celu całkowite zdyskredytowanie władz carskich. Redaktorzy i publicyści obwiniali władze carskie o głód, wojnę domową i doprowadzenie narodu do desperackiego wyjścia na ulice miast. Relacje z posiedzeń Rady Piotrogrodzkiej,

${ }^{8}$ „Izwiestija”, nr 208, 27 X 1917 r.

${ }^{9}$ https://eleven.co.il/jews-of-russia/public-life/13946/ Dostęp: 2018.12.29.

${ }^{10}$ Do 2017 roku zachowały się w Rosji dwa oryginalne egzemplarze pierwszego numeru gazety z 1917 roku. Rosjanie podkreślają, że od tego roku zmienił się format gazety, ale nie zmieniła się zawartość - dziennik nadal prezentuje oficjalne stanowiska władz rosyjskich. Ponadto gazeta znajduje się w czołówkach rankingów cytowalności wśród innych dzienników rosyjskich.

${ }^{11} \mathrm{http}: / /$ porto-fr.odessa.ua/index.php?art_num=art018\&year=2006\&nnumb=02 Dostęp [2019.09.10]. 
uchwalane dekrety oraz apele do towarzyszy partyjnych zdominowały całkowicie treść gazety w 1917 roku. Tytuły artykułów z tamtego okresu były silnie propagandowe, zwykle miały charakter odezw (np. „Do mieszkańców Piotrogrodu i Rosji” ${ }^{2}$ ), i były powtarzalne w treści.

\section{Ad. 2 „Prawda”}

„Prawda” to dziennik, który podobnie jak „Izwiestija” pojawił się z inicjatywy politycznej. Decyzja w sprawie utworzenia masowej gazety dla klasy robotniczej zapadła na Ogólnorosyjskiej Konferencji frakcji bolszewickiej Socjaldemokratycznej Partii Robotniczej Rosji SDPRR(b) w styczniu 1912 roku w Pradze. Pierwszy numer dziennika wyszedł w Petersburgu 5 maja (w dzień urodzin Karola Marksa), a nakład sięgał średnio 40 tysięcy egzemplarzy ${ }^{13}$. Pierwszym redaktorem naczelnym został Mikołaj Polietajew, rewolucjonista i bolszewik, który plan organizacji nowej gazety uzgodnił wspólnie z Włodzimierzem Leninem.

„Prawda”, w numerach 14 i 15 z 21 i 22 marca 1917 roku, opublikowała tezy Lenina dotyczące rewolucji, ale jak pisze polski historyk Józef Smaga, na początku przyjęto je sceptycznie:

(...) Jeszcze z Zurychu wysłał on do „Prawdy” Listy z daleka, ale zamieszczono - i to w wersji skróconej - z pięciu tylko pierwszy, bowiem wyrażane w nim myśli wydawały się awanturnictwem. Wśród redaktorów - cenzorów „Prawdy” był również Stalin. Podobne postulaty z „Tez kwietniowych”, które autor wygłosił w Piotrogrodzie, z równą trudnością przebijały się do świadomości bolszewików. Opublikowane trzy dni później w „Prawdzie”, opatrzono komentarzem redakcyjnym: ,nie do przyjęcia”'14.

Nakład „Prawdy”, która odegrała decydującą rolę w propagowaniu idei bolszewickich przed rewolucją październikową, wzrósł wtedy znacząco do 100 tysięcy egzemplarzy. Nic dziwnego, że po przewrocie rewolucyjnym gazetę uznano za najważniejszy tytuł prasowy w kraju. Redaktorzy gazety uważają do dziś, że historia gazety „Prawda” oddaje historię rewolucji, a jej wpływ nie ograniczył się tylko i wyłącznie do członków partii, ale obejmował sporą część społeczeństwa.

W odróżnieniu od „Izwiestii” w „Prawdzie” w 1917 roku pojawiło się kilka osobnych, a nie kontekstowych artykułów dotyczących Polski i Polaków, pokazujących ich wyłącznie z perspektywy partyjnej i bolszewickiej.

W skierowanej do narodu polskiego rezolucji, zamieszczonej na pierwszej stronie 10 numeru „Prawdy”, z 16 marca 1917, stwierdzono, że choć carski reżim niszczył polski naród na równi z rosyjskim, to teraz Piotrogrodzka Rada Żołnierskich Deputatów oświadcza, że Polska ma prawo być krajem niezależnym i przesyła Polakom braterskie pozdrowienia ${ }^{15}$.

12 „Izwiestija”, nr 1-28 II 1917 Dostęp 2019.09.09.

${ }^{13} \mathrm{http}: / /$ gazeta-pravda.ru/history/ Dostęp 2018.12.28.

${ }^{14}$ J. Smaga, op. cit., s. 26. Listy z daleka, 21 і 22 marca 1917 r. „Правда” Nr 14 i 15 http://www.revarchiv. narod.ru/vladimilitch/lenin31/lettre1.html Dostęp [2019.09.10].

15 „Prawda”, nr 10, 16 marca 1917 r. 


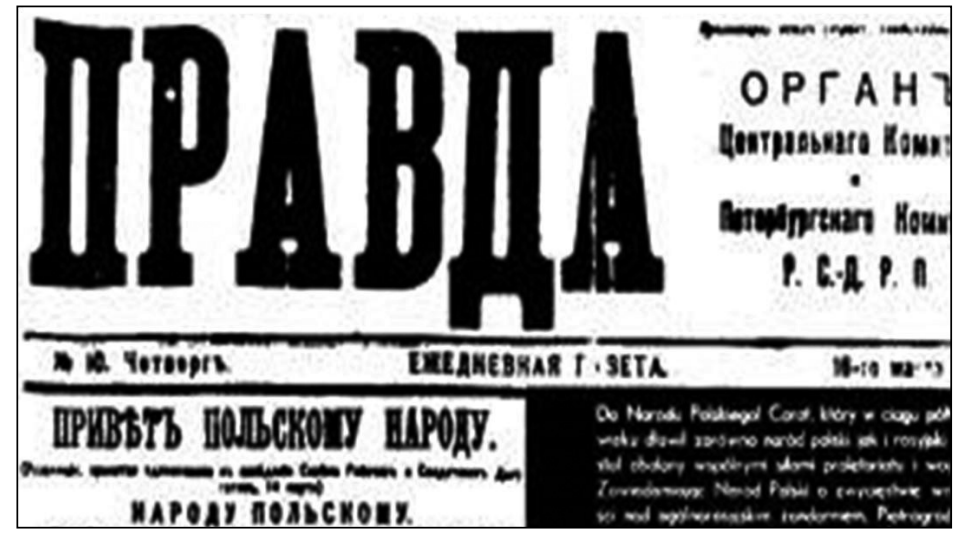

Fragment odezwy do narodu polskiego 16 marca 1917 roku gazeta pisze o niezależności Polski (Źródło: https://www.bbc.com/russian/russia/2012/05/120417_pravda_jubilee)

Kolejny tekst poświęcony Polakom dotyczył spotkania 3 marca 1917 r. członków socjaldemokracji Polski i Litwy, głównie ludzi uwolnionych z więzień po rewolucji. Uczestnicy spotkania jednogłośnie stwierdzili, że interesy polskiego proletariatu i całego narodu rosyjskiego wyrażane są przez rosyjski proletariat. A głównym hasłem propagowanym przez proletariat jest całkowite zniszczenie starego absolutyzmu.

(...) Rosyjski proletariat powinien zwrócić się do proleteriatu wszystkich walczących krajów z odezwą obalenia ich przestępczych rządów dla przerwania spowodowanej przez nich krwawej rzeźni i ustanowienia braterskich związków między narodami ${ }^{16}$.

„Prawda” wspomniała jeszcze o Polsce przy okazji ustawicznego pisania o rewolucji. W ocenie redaktorów Polacy, których przewrót wyprowadził na ulice, teraz powinni zrzucić jarzmo niemieckiego militaryzmu. Zwycięstwo rewolucji jest uzależnione od rozwoju ruchu robotniczego ${ }^{17}$.

\section{Podsumowanie}

Analiza jakościowa wybranych tekstów prasowych z „Izwiestii” i „Prawdy” pokazuje w pełni zideologizowaną perspektywę dziennikarską: niewielką liczbę artykułów poświęconych sprawom polskim w redakcji „Izviestii”, a nieco większą liczbę w redakcji „Prawdy”. Zarówno liczba opublikowanych tekstów poświęconych Polsce i Polakom w 1917 roku, jak i sposób pisania o niej odzwierciedla negatywne podejście do kwestii polskiej. „Prawda”, która szybko stała się symbolem sowieckiej propagandy, skupiła się na propagowaniu Polski bolszewickiej - o Polakach pisano pozytywnie tylko w kontekście tworzenia grup robotniczych, rozpowszechniania idei socjalistycznych i rewolucyjnych. Poza tym - jak podkreślano - gdyby wśród Polaków zwyciężyły idee rewolucyjne, trudna sytuacja

\footnotetext{
16 „Prawda”, nr 6, 1917 r., s. 62.

${ }^{17}$ „Prawda”, nr 41, 9 maja 1917, s. 216.
} 
Polski mogłaby ulec zmianie. Zwraca uwagę brak pogłębionych tekstów analitycznych, a powierzchowne opisywanie Polski w kontekście partyjnym. Zideologizowane tytuły prasowe, bezkrytycznie propagujące bolszewizm, nie mogły zatem wnosić obiektywnej wiedzy rosyjskim czytelnikom, budowały tylko stereotypowe wyobrażenie o Polsce i Polakach.

\section{Bibliografia przedmiotu i podmiotu:}

Adamowski J., Rosyjskie media i dziennikarstwo czasów przełomu (1985-1997), Warszawa 1998, s. 53.

Andruszewicz A., Nie tylko Dzierżyński, „Tygodnik Przegląd”, 11 grudnia 2017 r., roz. przepr.

P. Dybicz, https://www.tygodnikprzeglad.pl/nie-tylko-dzierzynski/ Data dostępu: 2018.12.29

Smaga J., Rosja w 20 stuleciu, Kraków 2001.

„Izwiestija”, nr 209, 28 października 1917 r.

„Izwiestija”, nr 208, 27 października 1917 r.

„Prawda”, nr 10, 16 marca 1917 r.

„Prawda”, nr 38, 5 maja 1917 r.

„Prawda”, nr 41, 9 maja 1917 r.

„Prawda”, nr 14 i 15, 21 i 22 marca 1917 r.

Netografia:

https://www.bbc.com/russian/russia/2012/05/120417_pravda_jubilee

https://eleven.co.il/jews-of-russia/public-life/13946/

http://gazeta-pravda.ru/history/

http://istmat.info/node/28027 (Archiwum wydań „Prawdy” z 1917 r.)

https://100.iz.ru/Gallery?gallery_id=8753 (Dekrety o pokoju i o ziemi z 1917 r.)

https://www.bbc.com/russian/russia/2012/05/120417_pravda_jubilee

http://www.revarchiv.narod.ru/vladimilitch/lenin31/lettre1.html

Agata Krzywdzińska, doktor, wykładowca, adiunkt w Instytucie Rosji i Europy Wschodniej Uniwersytetu Jagiellońskiego w Krakowie. Prowadzi zajęcia poświęcone rosyjskiemu systemowi medialnemu, obrazowi Polski w rosyjskich mediach, obszarowi euroazjatyckiemu w przekazach medialnych, manipulacji w kulturze medialnej, ideach oraz ideologiach współczesnej Rosji.

Dodatkowe zainteresowanie naukowe autorki: rosyjski model telewizji a amerykański model telewizji; dziennikarstwo śledcze i dziennikarstwo naukowe.

agata.krzywdzinska@uj.edu.pl

ORCID 0000-0002-9301-7332 